DOI: https://doi.org/10.34069/AI/2022.49.01.17

How to Cite:

Vorobey, P., Vorobey, O., Matviichuk, V., Niebytov, A., \& Khar, I. (2022). Criminal law principles in the fight against crime. Amazonia Investiga, 11(49), 156-164. https://doi.org/10.34069/AI/2022.49.01.17

\title{
Criminal law principles in the fight against crime
}

\section{Кримінально-правові принципи у боротьбі зі злочинністю}

Received: December 5, 2021

Accepted: January 22, 2022

\begin{abstract}
The purpose of the article is to analyze the criminal law principles in the fight against crime, to introduce a distinction between them and general principles of the State. The subject of the study is the criminal law principles in the fight against crime. Methodology. The following methods were used to achieve the goal of the Article: formal logic; description; historical and legal; comparative law; dogmatic. Results of the research. The paper analyzes and criticizes the criminal law principles in the fight against crime. Their essence and significance in the general context of combating crime are highlighted. Each principle is analyzed separately in the context of their relationship with the general principles of criminal law policy of the State. Practical meaning. It is proposed not to consider the principle of justice as criminal law one, but to place it within the framework of general philosophical principles and categories such as kindness, decency, humanism, humanity, honesty, etc. Value / originality. It is confirmed that the law on criminal liability must be fair, and therefore effective, which stems from the very matter of justice as a socio-philosophical category.
\end{abstract}

Анотація

Метою статті є аналіз кримінально-правових принципів у боротьбі зі злочинністю, їх відмежування від загальних принципів держави. Предметом дослідження $\epsilon$ кримінально-правові принципи у боротьбі зі злочинністю. Методологія. Такі методи були використані для досягнення цілей статті: формальної логіки; опису; історикоправовий; порівняльно-правовий; догматичний. Результати дослідження. У роботі піддаються аналізу та критиці кримінально-правові принципи у боротьбі зі злочинністю. Розкривається їх сутність i значення, роль і місце в загальному контексті протидії злочинності. Аналізується кожний принцип окремо через призму їх взаємозв'язку із загальними принципами кримінально-правової політики держави. Практичне значення. Пропонується принцип справедливості не вважати кримінальноправовим, а віднести його до системи загально філософських принципів та категорій "доброти", "гуманності", "людяності", "чесності", "порядності", тощо. Цінність / оригінальність. Підтверджується те, що закон про кримінальну

\footnotetext{
${ }^{64}$ Doctor of Law, Professor, Head of the Department of Criminal Law, Procedure and Criminology of Kyiv Institute of Intellectual Property and Law of the National University "Odesa Law Academy", Ukraine.

${ }^{65} \mathrm{PhD}$ in Law, Associate Professor, Professor of the Department of Forensic Support and Forensics of the Educational and Scientific Institute № 2 of the National Academy of Internal Affairs, Ukraine.

${ }^{66}$ Doctor of Law, Professor, Professor of the Department of Criminal Law, Procedure and Criminology of Kyiv Institute of Intellectual Property and Law of the National University "Odesa Law Academy", Ukraine.

${ }^{67}$ Doctor of Law, Associate Professor, Head of the Main Department of the National Police in the Kiev region, Ukraine.

${ }^{68}$ Candidate of Law, Associate Professor, Head of the Department of Postgraduate and Doctoral Studies of Kyiv Institute of Intellectual Property and Law of the National University "Odessa Law Academy", Ukraine.
} 


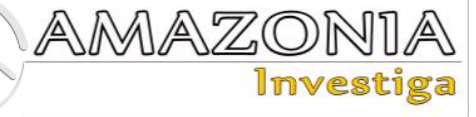

Key words: concepts, criminal law principles, interrelation, legal categories, philosophical categories. відповідальність повинен бути справедливим, а значить і ефективним, що витікає із самої матерії справедливості, як соціальнофілософської категорії, а не принципу.

$\begin{array}{lcc}\text { Ключові } & \text { слова: } & \text { кримінально-правові } \\ \text { принципи, } & \text { філософські } \\ \text { взаємозв'язок, правові категорії, поняття. }\end{array}$

\section{Introduction}

Criminal law principles are a kind of foundation of State's criminal law policy in the fight against crime. They reflect not only the tasks of the State in this area, but are important for legislative activity. These principles are a kind of regulator and benchmark for law enforcement as well. This, in turn, is the appropriate guarantor of the right policy of the State, its validity and legality. Criminal law principles are the link between forensic activity and the whole set of norms of legislation on criminal liability. Can the principles of criminal law policy fully cover the criminal law principles in the area of fighting crime? Two categories of principles reflect their legal nature, the search for selection criteria, formulate the guidelines of public policy, and reveal their content and meaning of existence.

They coincide in many ways and relate as legal matter. The principles of criminal law policy are reflected in general terms and are a relative specification for a particular area. These principles should be distinguished from criminal law principles. The principles of criminal law policy have a larger scope in terms of integrative processes, while criminal law principles exist for specific tasks in fighting crime. The former cannot be considered criminal law ones, as they are the basis of all legal policy of the State.

The need to take equity outside the system of criminal law principles is due primarily to the fact that this is not a principle in nature, but a philosophical category. Criminal law principles have specific, unique features and legal matter. The category of "justice" has a philosophical direction and occupies a corresponding place in the system of general philosophical categories, such as kindness, decency, humanism, honesty, humanity, etc.

Global processes of our time force to be in constant search for regulation of new social relations, which is the basis for public policy. One of such tasks is the State's criminal law policy of the State in the fight against crime. Relevant State institutions are established, judicial and law enforcement systems are reformed, domestic legislation in general and the legislation of Ukraine on criminal liability in particular are improved to solve this problem. The basis for solving these problems is criminal law principles in fighting crime. The entire State's criminal law policy depends on their observance and application. This issue has recently received due attention, but different views of scientists and law enforcement indicate the existence of unresolved issues. This applies primarily to the issue of assigning different principles to one system, which is a misconception. Scientists have come to believe that such categories exist in the system of principles, which are generally in the system of general philosophical categories.

Thus, the aim of the study is the attempt to analyze the criminal law principles in the fight against crime in more detail, to distinguish them from the general principles of the State's criminal law policy. It is proposed to remove the category of "equity", which is called the principle of justice, from the system of criminal law, because it belongs to such categories as kindness, decency, humanism, honesty, humanity, etc. by its socio-philosophical nature. This will enable the State to carry out its tasks in combating crime in a more specific and professional manner.

\section{Methodology}

The choice of the methods of the research is determined by the characteristics of the purpose, objectives, object and subject of the research.

In particular, the dialectical method allows to consider the criminal law principles in the development and taking into account the basic laws of dialectics.

Historical method involves the study of the principles of criminal law in their historical development. It is a tool for understanding the present and predicting the future. The application of this method determines: recourse to the analysis of relevant historical criminal law sources; consideration of the formation, 
development and functioning of criminal law principles in domestic and foreign legislation; research of the relevant normative legal acts, etc.

Dogmatic method provides commentary on the principles of criminal law of Ukraine and the practice of their application, as well as serves to systematization of criminal law principles, disclosure of their essence, clarifying the content of certain principles by interpreting them.

The method of systematization allows to demonstrate the internal construction of the norms, from which the principles of criminal law follow, their relationship and interdependence with other criminal law concepts and categories.

Synergetic method allows to expand and enrich the concepts and categories of criminal law principles.

\section{Literature Review}

Principles play a significant role in legal activity, as they first of all consolidate law-making and justice, give internal integrity to the current legal system, and guarantee the realization of the rights and interests of Ukrainian citizens. They ensure the unity of the process of implementation and determination of the effectiveness of legal policy of the State (Maksymiv 2016, p. 87). In this regard Chernyshevskyi (1949, p. 225) once rightly remarked that "Who has unconscious principles in all logical comprehensiveness and consistency, has not only mess in his head, but in the affairs as well".

Principles are not only the basis for any branch of law, but also the basis for public policy, including criminal law and criminal procedure policy and are fundamental, defining ideas. Dal (1998, p. 431) defines the principle as the scientific or moral basis, the basic rule, the base from which there is no retreat. Beliaiev (1986, p. 21) correctly states that "any policy should be principled and based on certain fundamental ideas".

Fris (2005, p. 126) highlights the principles of criminal law policy; Zahurskyi (2014) speaks about the principles of criminal procedural policy of Ukraine. According to Lopashenko (2012, p. 155), the principles of criminal law policy in general are separate results of such a policy, which includes the formation of the principles of criminal law influence on crime; they consist of the principles of criminal law and the principles of law enforcement.
Baldwin (1912) formulated the fundamental principles of criminal justice: 1.the person must be duly informed of the charge against him (her), and have the right to the proper legal aid; 2 . the court, which hears the case, should be competent and independent; 3 . The judgment should be pronounced by that court; 4. it must be immediately brought to the attention of the convicted person. 5. it must be commensurate with the gravity of the crime and be fair.

Jerome Hall (1960) stated that the criminal law can be analyzed at different levels of abstraction. At the lowest level are the specific rules defining individual crimes. Criminal law doctrines are at a higher level of abstraction. Doctrines are conceptually broader than rules and sometimes override their application. General principles of the criminal law are at the highest level; they provide theoretical basis explaining what is common to crime and which Professor Hall describes as "the ultimate norms of the penal law".

Robinson (2021) identifies the following core principles of criminal law: the punishment principle: wrongdoing deserves punishment; the meaning of wrongdoing; the blameworthiness principle: blameless conduct should be protected from criminal liability; the proportionality principle: the extent of liability and punishment should be proportionate to the extent of wrongdoing and blameworthiness; constructing a criminal code.

\section{Results and Discussion}

The activities of any State in general and the activities to combat crime in particular, should be based on conceptual, based on the methodological foundations of the provisions and conclusions.

In order to justify its purpose, the activities of the State must be transparent, based on an appropriate system of ideas and principles.

With the range of appropriate theoretical and practical approaches to combating crime in the State its institutions are stable; there is a high level of legal awareness of civil society and trust in the current government. Solving important issues of the State in the fight against crime is impossible without the established principles constituting them. Such principles express and reflect the specified tasks of the State. It is equally unrealistic to implement criminal policy outside and through the system of its principles: 


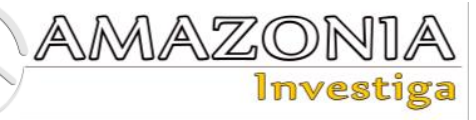

in many ways, it is the principles enshrined in the law that give effect to it (Dahel 1982, p. 31).

Criminal law principles are important in the legislative process, as they should be reflected in the light of the guiding ideas of State policy in the fight against crime. Prior to the adoption of the relevant law, the activities of the State should be aimed at the necessity, validity and social conditionality of its adoption. After the adoption of such a law, its effectiveness largely depends on the degree of consideration in the law-making process of criminal law principles. Criminal law principles keep the legislation on criminal liability within certain limits and indicate the correct direction and expediency of its formation. They provide an opportunity to ensure the necessary unity and stability. The regulation of law enforcement activities are criminal law principles. These principles are an appropriate guide for practical activities in the fight against crime. Such activities are carried out in accordance with current legislation and are consistent with the State policy on this issue. State control over such activities serves as an appropriate guarantor of its correctness, necessity, reasonableness and legality.

Their understanding in civil society plays a significant role in the adoption of criminal law principles in fighting crime. The practice of combating crime shows that in the legal consciousness of society, respect for legal principles is much more important than knowledge of specific criminal law.

We must agree with Filimonov (2002, p. 11), who notes that "the role of the principles of criminal law is to serve as a mediating and connecting link between forensic activities and the whole set of legal norms that form criminal law".

Criminal law principles are a kind of foundation of State policy in the fight against crime, which is only a relevant element of this fight. This raises the question of whether the principles of criminal law policy can fully embrace the criminal law principles in the sphere of fighting crime. Surely, they cannot. Two categories (groups) of principles reflect their legal nature, the search for selection criteria, formulate the guidelines of public policy, revealing their content and meaning.

The main provisions, ideas, views, approaches underlying the tasks of the fight against crime form the theoretical foundations for the principles of public policy in this fight. Scientific knowledge of laws, legislation, various government agencies, political parties, associations, public organizations and unions are the basis for the development of these principles. Scholars perceive and understand these principles in the fight against crime in different ways, taking into account the practice of applying the relevant norms and principles.

This demonstrates the depth and importance of the challenge facing State policy in combating crime. Speaking about the definition of criminal law principles, Kovalev (1971, p. 18) notes that the "stage" at which the work is carried out is characterized as the stage of single and "unorganized" searches, where every researcher wanders around in a chaotic accumulation of material, "scoops out" separate legal concepts, definitions, specific features and at their own risk "rewards" them with the titles of the principles of criminal law. This is fully consistent with the fact that these principles can be applied to characterize the study of principles of State policy in the fight against crime.

They coincide in many ways and relate as legal matter. However, these principles should not be compared, although they are close to each other, but there is a difference between them. Some scholars (including Maltsev (2004, p. 275)) believe that criminal law principles are primary in relation to the State's criminal law policy principles and the role of the latter is subordinate and official, which is to more accurately and fully reflect the content of the principles.

We can hardly agree with this view, as the principles of State policy in the fight against crime are not enshrined in law and can be reflected in any policy documents of the State level. The principles of State policy in the fight against crime are reflected in general terms and are the appropriate specification for a certain direction. In general, it is obvious that the principles should be distinguished from criminal law principles, which perform the specific tasks in the fight against crime. When characterizing the principles of criminal law, first of all we should focus on the basic ideas and principles in the area of combating crime, through which the law on criminal liability forms criminal remedies for this fight and the practice of their application. The above shows that these principles are a kind of component of public policy in the fight against crime. The principles of humanism and justice are inherent in any sphere of the state, but the first manifests itself more clearly in the public policy of the fight against crime, and the second one is intrinsic to criminal policy. There is a certain 
relationship and interdependence between these principles, which indicates their relationship.

The principles of the State policy in the fight against crime are decisive in the nature of the legislation on criminal liability and the practice of its application. They are the constituent principles of the law on criminal liability. At the same time, they differ from each other, as the principles of State policy are the main factors in the formation of criminal law principles. The latter are concretized precisely on the basis of the principles of State policy. From the point of view of objective perception of the specified principles, they are inextricably linked among themselves by legal matter, and therefore are perceived at first sight equally. If we analyze these groups of principles in more detail, not all criminal law principles are among the principles of State policy. However, the latter are important because they contain guiding and principled ideas of State policy in the fight against crime.

The principles of State policy reflect not only the diverse interests of society in the fight against crime, but also the very specifics of this fight, which is characteristic of the law on criminal liability.

Criminal law principles are based on the general principles of the legal policy of the State, including in the area of combating crime.

General principles are at a higher level and determine the principles of legal policy of the state as a whole. They are not part of the system of criminal law principles. Boskholov (1999) restricts these principles at the level of general principles without specifying those that define the State policy in the fight against crime. This point of view is not convincing because it does not have a sufficient scientific basis.

The criminal law principles include:

- the principle of compliance of State policy in the fight against crime with other elements of this policy;

- the principle of taking into account socio and legal psychology;

- the principle of saving repression;

- the principle of expediency;

- the principle of inevitability of responsibility;

- the principle of differentiation and individualization of responsibility and punishment;

- the principle of social justice.
In our opinion, the principles should have a different title than the one proposed by Fris $(2005$, p. 53). The very legal nature of these principles suggests that they are the reflection of the State's struggle against these criminal norms of criminal law. The name of these principles proposed by Fris is general in nature and does not reflect the specifics of activities in the fight against crime, which is inherent in the rules of substantive law. Moreover, these principles cannot be considered criminal law, as they are general principles that underlie the legal policy of the state as a whole.

Further, Fries (2005) notes that the general principles are not included in the system of principles of criminal law policy, as they are at a higher level, defining the principles of legal policy of the Ukrainian state as a whole. So it is precisely these general principles that are the principles of the State's criminal law policy, and not the criminal law principles in the fight against crime.

It is clear that the proposed name of the principles by Fris (2005) is not absolute. This suggests that there are still many gaps in this issue that need to be addressed in future research.

State policy in the fight against crime is part of the overall State policy. It plays an extremely important role and is a key element in establishing criminal activity. All other elements of the former exist in the context of certain criminal law principles.

These principles may not always determine certain elements of State policy in the area of combating crime. The lack of such a possibility is explained by the fact that some of these principles have their own, unique characteristics. However, being in one system of principles, they should not contradict the other ones. Such a contradiction can lead to an imbalance in the work as a whole and the solution of problems in the fight against crime.

In the criminalization process, the legislator, first of all, should take into account socio-legal psychology, historical traditions and ideas about crime and non-crime, moral and ethical categories and other values. There are the objective laws of the development of nature, humanity, the State. The very existence of mankind is under the influence of these laws. But in the process of the existence the person also influences these laws (positively and negatively), drawing positive components for his (her) existence and development. The same approach 


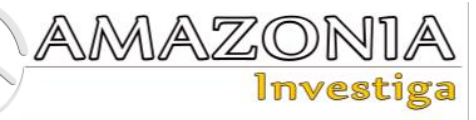

to resolving interethnic and religious issues can lead to negative consequences, as the social and legal psychology of the people differs greatly. At the same time, the perception of social values of different nationalities is completely different not only in relation to individual States, but also within the State itself. Therefore, it is not only social and legal attitudes at the international level that are controversial, but there are also interstate conflicts. These are, for example, conflicts between some Balkan countries, the Middle East, the countries of the African continent, etc. National minorities living on the territory of Ukraine have their own system of social and legal coordinates, which is taken into account in the process of combating crime. The implementation of the State program in such a struggle takes into account the social and legal psychology of all nationalities living in Ukraine. Article 24 of the Constitution of Ukraine (Law of Ukraine No. 254k/96-VR, 1996) states: “Citizens have equal constitutional rights and freedoms and are equal before the law. There shall be no privileges or restrictions based on race, colour of skin, political, religious and other beliefs, sex, ethnic and social origin, property status, place of residence, linguistic or other characteristics". Failure to observe and ignore the principle of conformity of public policies can lead to negative consequences, the emergence of interethnic and interfaith conflicts. Criminal law regulations will be ignored and not enforced, which may lead to massive violations of the law by the general public.

Criminal law principles reflect the policy of the State in the fight against crime, which is a peculiar reflection of the principle of economy of repression ("minimum minimorum"). It is an indicator of State policy at all stages of its implementation. If it is necessary to classify the relevant action as one that should be combated by criminal law, the above-mentioned principle plays an important role in this matter. After all, it determines the degree of public danger of the act and solves the question of applying the necessary measures of influence. Exaggerating such measures can only lead to negative consequences. If a positive result can be achieved only by applying harsh measures of influence, then criminal repression is inexpedient and harmful.

The need for criminalization should be determined by its expediency and contain such penalties, types and amounts that would allow to minimize punitive elements to solve the tasks set before the law. Excessive repressive policies resemble the "boomerang" principle, where the desire to establish control over "everyone and everything" leads to irreparable consequences. This is a gross violation of the principle of economy of repression. The norms adopted in violation of this principle are unjustifiable and harmful. Criminal law instruments should be cost-effective and lead to the desired results. This means that such a result can be achieved without the actual application of punishment. If it is possible to release a person from criminal responsibility and punishment, it is necessary to apply the rule of law for his (her) release, confirming the principle of economy of repression.

Positive result in the fight against crime will take place only when the means of influencing the perpetrator are the least repressive. This approach to solving this important issue has a huge positive effect and a correct understanding of criminal law principles in practice. In this case, a kind of psychological arrangement for law enforcement and judicial authorities on the use of exclusively punitive methods of combating crime is made. This principle ("minimum minimorum") is organically combined with the principle of expediency, as the latter also reflects the purpose of the application of measures of criminal law influence.

It is advisable not to overstate the possibilities of criminal repression and to avoid excessive liberalization (mitigation). This principle is a kind of result of the choice and application of criminal repression in practice. The main task of these measures is to combat crime in general, correction and re-education of individual offender in particular (general and special prevention). The principle of expediency is inherent not only in the fight against crime and lawmaking. It is in general a kind of barometer of social life in general and of each individual in particular. Methods and techniques to combat crime will be justified if they are substantiated in terms of their feasibility. Only then can we talk about legality and justice. In practice, there are many cases of deviation from this principle, which entails a violation of criminal law. Such consequences cannot be justified by any expediency or inexpediency.

In law enforcement, these principles are mainly taken into account the purposes of punishment (Tkachevskyi 1970, p. 7). It is difficult to agree with this view; such narrow interpretation does not comply with the principle of law at all. Moreover, such a principle cannot be considered in terms of criminal law principles. 
To this we may add the need to share "supportive" measures in the process of implementing the principle of feasibility where required by specific criminal policy objectives in combating anti-social behaviour of particular individuals.

Therefore, in accordance with the principle of expediency, all measures of criminal law influence should be defined, applied and used there to ensure the achievement of the goals set before them.

Among the criminal law principles in the fight against crime, the principle of inevitability of responsibility occupies an important place, as it detects and discloses crimes, prosecutes perpetrators, applies penalties and compensates for the damage caused by the crime. This principle is a kind of general prevention, as it demonstrates the capacity of the law to combat crime.

However, the law's capacity to combat crime is restricted. The legislator influences the level of crime by adopting new laws, sometimes without taking into account many objective factors (economic situation, mass diseases, etc.). There is a situation when law enforcement agencies cannot fight crime to a certain extent, using the opportunities provided by law. As a result, crime detection and prosecution rates are low. The result of such ineffective work is the unjustified and excessive criminalization of various acts that cannot be classified as crimes due to the degree of public danger.

This leads to disillusionment with the law enforcement system in society and unjustified and unreasonable involvement of human and material resources. This state of affairs has a negative impact on the fight against crime in general. Therefore, when starting work on any bill, this principle should be taken into account as the main principle for future tasks to be performed by the adopted law. When adopting the law on criminal liability, the legislator knows in advance that the above principle will be implemented through the prism and punishment is an inevitable consequence of the crime.

However, this principle cannot be reduced to the application of punishment. It also plays crucial role in the introduction of other measures of criminal law influence. In this case, there is no contradiction between the principles and their obvious organic unity and relationship. The use of various methods of responding to the crime confirms the fact that the position of the State in the fight against crime remains stable. This is another confirmation of the State's adherence to criminal law principles in the fight against crime in general and the principle of inevitability of punishment in particular.

The analyzed principle organically combines criteria that are also inherent in the principle of differentiation and individualization of responsibility and punishment. The latter makes it possible to proportionally apply the provisions of the law on criminal liability not only in terms of repression but also to decide on the application of other measures of criminal law influence. Any legislation in general and national one in particular provides clear guidelines for the application of appropriate methods of influencing different categories of perpetrators. It is no coincidence that the legislation of Ukraine on criminal liability contains sections providing for different types and levels of penalties and exemptions (sections X, XI, XII, XV of the General Part of the Criminal Code of Ukraine) (Law of Ukraine No. 2341-III, 2001)).

In the implementation of this principle important is the balance of general and special rules, analysis and search for the features of the crime and connection between different legal phenomena. The search for and the elimination of contradictions in the legal evaluation of the acts committed is evident.

Strict requirements of individualization of responsibility and punishment should be observed when applying the norms of the law on criminal responsibility. To do this, first of all one needs to take into account the nature and severity of the act, the reasons and conditions of its commission, the identity of the perpetrator and other circumstances. Mitigating and aggravating circumstances are also important. Through the prism of all these circumstances, the individualization of criminal responsibility and punishment acquires its legal significance and becomes an important component of this principle. The study of the concept of justice goes back a long time, beginning with the since the advent of man on earth.

At first glance, this category is not relevant to legal science, given that laws and other regulations should be above all just, as they reflect the social and legal nature of the society and the State. However, as centuries of practice have shown, not all laws have been just and do not meet the criteria to be met by social law. 


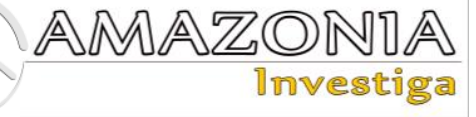

Changing socio-economic formations and the emergence of new social relations and their regulation have forced legal science to use and explore such a category as justice. In our opinion, justice is a kind of middle ground between opportunity and outcome. Moreover, this issue is subjective and evaluative and is more sociophilosophical than legal one. However, legal science has accepted this category as legal and uses it as a principle of justice. The legislator uses the term "justice" when establishing a criminal prohibition to define the rules of conduct and their limits. Therefore, this principle of justice is abstract and declarative in nature and it is more philosophical than legal one. Marks noted that justice is "the most abstract expression of law itself” (1961, p. 273).

Fris $(2005$, p. 61) states that the attribution of justice to the principles of Ukrainian criminal law policy allows to take it beyond the narrow legal framework, fills it with legal content, emphasizes the political importance of justice in the fight against crime.

It is difficult to agree with this statement, because the very concept of "justice" is much more significant and performs functions that are inherent in any sphere of public life. It seems that only criminal law policy, according to professor Fris, paved the way for the principle of justice in the fight against crime.

The multifaceted nature of justice as one of the criminal law principles in combating is extremely significant. This category permeates all law-making and law-enforcement activities. In deciding whether to criminalize or decriminalize an act, the public interest should be taken into account by the legislator. The criterion of equity is sufficiently precise and can be said to be a sensible standard for assessing the degree of responsibility of a social norm to public interests (Kudriavtsev 1972, p. 176). It's accurate, but it's logical.

The change in public relations requires the improvement of legislation on criminal liability, which is non-static. Some norms supplement the current legislation; the others lose their meaning and are subject to decriminalization. What role does the category of justice play in this case? It allows for an objective assessment of the role of a norm the legal system and prediction of further rule-making activities. The legislator should always monitor the mood of public opinion and, if necessary, respond to society's request to regulate public relations in the fight against crime. There are many norms in the legislation of
Ukraine on criminal liability that are not effective enough and their public danger does not correspond to the signs of a crime. It is no coincidence that these crimes are classified as criminal offenses. Very little jurisprudence exists for crimes against the peace, security of mankind and the international legal order (Chapter XX of the Special Part of the Criminal Code of Ukraine) (Law of Ukraine No. 2341-III, 2001)). This indicates that the possibilities of these norms are not fully used, although such crimes as war propaganda (Article 436 of the Criminal Code), piracy (Article 446 of the Criminal Code) and mercenary (Article 447 of the Criminal Code) are committed quite often in the world.

\section{Conclusion}

Any criminal law norm contains an element of justice by its legal nature, as it arises for the settlement of relevant social relations. The responsibility for committing crime is punishment, i.e. the reaction of society, the State to the violation of justice and aimed at protecting justice. In this case, the relationship between crime and punishment is traced. Such a reaction of the law to the crime is a kind of confirmation of this category. However, even if there was no category of justice in criminal law, this relationship between crime and punishment would be based on the formal logic of the formula "crime - responsibility - punishment".

As Karpets (1973, p. 92) correctly points out: "punishment should adequately reflect the views of the people on crimes, on the perpetrators, on measures to combat crime." Therefore, when adopting the law, special attention should be paid to the construction of sanctions of criminal law, which should take into account the idea of justice of punishment for the crime. It is in this area of law that the category of justice and conviction in the correctness of the court's decision is manifested. Yakovlev (1982, p. 93) emphasizes: "without coercion, criminal justice would be powerless, without education, not humane". However, the category allows a variety of tools of criminal-legal influence on persons who have committed a crime to be used in practice; and, where necessary, various types of exemption from criminal responsibility to be widely applied.

It should be noted that the disadvantage of domestic legislation is primarily that to date, no criminal law principles have been enshrined in law in the fight against crime.

In this regard, a logical question arises: can such a philosophical category as justice be a criminal 
law principle at all? In our opinion, it cannot. The effectiveness of fair criminal liability laws is due to the fact that justice for them derives not only from lawmakers, but also from citizens. That is, as we see, this is not about the principle of justice, but about the category of justice. The law on criminal liability can be fair when it is in conformity with the natural law of social (including economic) exchange between people. This is further evidence that the law on criminal responsibility must be fair, and therefore effective, which stems from the very matter of justice as a socio-philosophical category.

In conclusion, it should be noted that the socalled principle of justice is one of the criteria in the fight against crime and should not be in the system of criminal law principles. This is a separate philosophical category, which occupies an appropriate place in the system of general philosophical categories, such as kindness, decency, humanism, humanity, honesty, etc. (Kostenko 2008, p. 256).

\section{Bibliographic references}

Baldwin, S. E. (1912). The fundamental principles of criminal justice. Yale Law Journal, No. 22, pp. $30-38$.

Beliaiev, N. (1986). Criminal law policy and the ways to implement it: monograph. Leninhrad: Publishing house of Leninhrad State University. (In Russian)

Boskholov, S. (1999). Fundamentals of criminal policy: constitutional, criminological, criminal and informational aspects. Moscow: YurInfoR. (In Russian)

Chernyshevskyi, N. (1949). Complete collection of works: in 15 Volumes. Volume 2. Articles and reviews of 1853-1855-1949. Moscow: Hoslitizdat.

https://royallib.com/book/chernishevskiy_n/pol noe_sobranie_sochineniy_v_15_tomah_tom_2 stati_i_retsenzii_18531855 1949.html

Dahel, P. (1982). Problems of Soviet criminal policy. Training manual. Vladivostok: Publishing house of the Far Eastern University. http://lawlibrary.ru/izdanie21156.html

Dal, V. (1998). Explanatory Dictionary of the Great Russian language. Moscow: Tsitadel.

Filimonov, V. (2002). Principles of criminal law. Moscow: YurInfoR.

Fris, P. (2005). Criminal and legal policy of Ukraine. (Doctoral Dissertation). National Academy of Internal Affairs of Ukraine. http://www.disslib.org/kryminalno-pravovapolityka-ukrayiny.html

Hall, J. (1960). General principles of criminal law ( $2 \mathrm{~d}$ ed.). Indianapolis, IN: Bobbs-Merrill.
Karpets, I. (1973). Punishment. Social, legal and criminological problems. Moscow: Legal Literature.

https://www.twirpx.com/file/908012/

Kostenko, O. (2008). Culture and law in the fight against evil: monograph. Kyiv: Atika. ISBN: 978-966-326-281-9

Kovalev, M. (1971). Soviet criminal law: Course of lectures. Issue. 1: Introduction. Sverdlovsk: Eksmo. http://lawlibrary.ru/izdanie5079.html

Kudriavtsev, V. (1972). General theory of crimes qualification. Moscow: Legal Literature. http://adhdportal.com/book_1550.html

Law of Ukraine No. 254k/96-VR. The Constitution of Ukraine. Official Web site of the Verkhovna Rada of Ukraine, June 28, 1996, No. 254k/96VR. Available online. https://zakon.rada.gov.ua/laws/show/254\%D0 \%BA/96-\%D0\%B2\%D1\%80\#Text

Law of Ukraine No. 2341-III. (2001). Criminal Code of Ukraine. Official Web site of the Verkhovna Rada of Ukraine, April 05, 2001, No. 2341-III. Available online. https://zakon.rada.gov.ua/laws/show/234114\#Text

Lopashenko, N. (2012). Sound Criminal Policy and Tomorrow's Russian Criminal Code: Ideas and Ideals. In the collection: Modern criminal policy: search for the optimal model of the materials of the 7th Russian Congress of Criminal Law. Moscow: Prospekt. (In Russian)

Maksymiv, O. (2016). Theoretical basis of the policy of Ukraine in the sphere of counteraction crimes. ( $\mathrm{PhD}$ Dissertation). Lviv State University of Internal Affairs of the MIA of Ukraine.

http://dspace.lvduvs.edu.ua/bitstream/1234567 890/678/1/maxsymiv\%20aref.pdf

Maltsev, V. (2004). Principles of criminal law and their implementation in law enforcement. SaintPetersburg: Legal Center Press.

Marks, K. and Enhels, F. (1961). Essays. Vol. 18. Moscow: State Publishing House of Political Literature.

https://www.marxists.org/russkij/marx/cw/t18. pdf

Robinson, P. H., (2021) "Criminal Law's Core Principles". Faculty Scholarship at Penn Law. 2251.

https://scholarship.law.upenn.edu/faculty_scho larship/2251

Tkachevskyi, Yu. (1970). Exemption from serving a sentence. Moscow: Legal Literature. http://lawlibrary.ru/izdanie10997.html

Yakovlev, A. (1982). The principle of social justice and the basis for criminal responsibility". In: Soviet State and Law, No. 3, pp. 88-94.

Zahurskyi, O. (2014). Criminal procedural policy of Ukraine: historical and legal aspect: monograph. Ivano-Frankivsk: Foliant. (In Ukraine) 